\title{
A Study from a Country with High Number Population: Risk Factors Associated with Low Back Pain among Middle-Aged Adults
}

\section{Tashya Anggraeni Sinaga}

Universitas Pembangunan Nasional Veteran Jakarta

Feda Anisah Makkiyah ( $\nabla$ fedaanisah@upnvj.ac.id)

Universitas Pembangunan Nasional Veteran Jakarta

Namira Khairunnisa

Universitas Pembangunan Nasional Veteran Jakarta

\section{Research Article}

Keywords: Low back pain, Middle age, Risk factors

Posted Date: September 24th, 2021

DOl: https://doi.org/10.21203/rs.3.rs-659263/v1

License: (c) This work is licensed under a Creative Commons Attribution 4.0 International License.

Read Full License 


\section{Abstract}

BACKGROUND: Low back pain is a global health problem that affects the productivity of the patients. Several factors such as individual, occupational, and psychosocial factors increase the risk of low back pain. However, only a few studies investigated those factors, especially in middle adulthood in Indonesia.

AlM: This study was conducted to find out the factors associated with low back pain in middle adulthood.

METHODS: This study is a cross sectional- observational analytic study using a convenience sampling method with a total sample of 3005 respondents. Data were collected using a questionnaire which was then analyzed using the Chi-square test, Kolmogorov Smirnov, Spearman's Rank, and logistic regression test.

RESULTS: From the result of this study, it was found that the 12-month prevalence of low back pain in middle-aged adults was $44,29 \%$. Female ( $\mathrm{p}$-value $=0,002 ; \mathrm{OR}=1,3 ; 95 \% \mathrm{Cl}=1,098-1,545$ ), lack of physical exercises ( $p$-value $=0,005 ; O R=0,87 ; 95 \% C l=0,794-0,959$ ), high body mass index ( $p$-value $=0,002$; $\mathrm{OR}=1,09 ; 95 \% \mathrm{Cl}=1,009-1,187)$, stress level ( $\mathrm{p}$-value $=0,002 ; \mathrm{OR}=1,26 ; 95 \% \mathrm{Cl}=1,088-1,458$ ), and working time ( $p$-value $=0,047 ; \mathrm{OR}=1,1 ; 95 \% \mathrm{Cl}=1,001-1,225)$ were determined as risk factors that significantly associated with low back pain.

CONCLUSION: Middle-aged adults in Indonesia have a quite high prevalence of LBP. The possible risk factors associated with LBP among middle-aged adults were female gender, higher body mass index, lack of physical exercise, stress level and working time. Middle-aged adults in Indonesia should be aware of LBP by identifying risk factors that might potentially worsen LBP in the future and avoid disabilities.

\section{Introduction}

Low back pain (LBP) is the most common musculoskeletal complaints and the most frequent causes of life with disabilities. The prevalence is ranged from $20-33 \%$ in all patients with musculoskeletal pain complaints worldwide. Low back pain is a complaint that is not only experienced by elderly people but also be found in all age categories including productive adults. ${ }^{(1)} \mathrm{A}$ study in the United States shows that low back pain occurs in one to three adults under the age of 65 each year, which indicates that middle adults (30-60 years) are likely to develop low back pain. ${ }^{(2)}$ Middle adulthood, referred to as the transitional period, is a period that is marked by changes both physically and psychologically. A study shows that the peak of productivity is performed by middle adults aged $40-45$ years. $(3,4)$

There are many risk factors that affect the prevalence of LBP in middle adulthood. These factors are namely divided into three categories; individual, occupational, and psychosocial factors. Age, gender, body mass indeks (BMI), family history of illness, smoking habits, alcohol consumption, being married, female, and lack of routine exercises are categorized as individual risk factors. ${ }^{(5)}$ Whereas, occupational risk factors, for examples $11-80 \%$ of these factors are involved in ergonomic factors such as sitting over, 
lifting weights, and bending over. ${ }^{(6)}$ The population with the highest prevalence of LBP in small city in West Jawa, Jatinangor is the productive age (18-65 years). This is possibly due to the high physical and occupational loads that demanding a certain body position during work for prolonged period of time. ${ }^{(7)}$

Although various studies have examined the incidence, prevalence, and risk factors for LBP in middle adulthood, only a few research has studied regarding the prevalence and risk factors of LBP especially among middle-aged adults in Indonesia, a country with the fourth rank of the number of population with the productive aged people is in the highest proportion of population (15-64 year, $70.72 \%)^{(8)}$. In addition,

low back pain could cause economic losses and decreased productivity of the patients. ${ }^{(9,10)}$ Therefore, it is important to identify both modifiable and non-modifiable risk factors to prevent LBP. Based on the reasons mentioned above, this study was conducted to determine factors associated with low back pain among middle-aged adults in Indonesia.

\section{Material And Methods}

\section{a. Study design and participants}

A total of 3005 Indonesian middle aged adults were included of whom 1681 were male and 1324 were female. All participants gave consent and approval before filling ed the questionnaires in google forms. Data were collected from February 4-March 27, 2021. The sociodemographic and occupational related questions, low back pain questions and perceived stress scale questionnaire were included.

This study was approved by Clinical Study Ethics Commitee of Pembangunan Nasional Veteran Jakarta University (57/I/2021/KEPK). The respondents had given the approval by informed consent to participate in this research. All methods were carried out in accordance with the Declaration of Helsinki."

\section{b. Outcome Measures}

\section{Assessment of Low Back Pain}

Participants' low back pain events within the last 12 months were evaluated using low back part of Indonesian version of Standardized Nordic Musculoskeletal Questionnaire which was translated by Chairani (2013). Reliability score of this questionnaire was tested by Wicaksono (2019) with a result of cronbach's alpha score of 0.945 . Therefore, all items in this questionnaire is valid and reliable. ${ }^{(11)}$

\section{Assessment of psychosocial risk factors}

Stress levels of participants were evaluated through Perceived Stress Scale (PSS-10). Perceived Stress Scale is a 10 -item questionnaire which uses likert scale where " $0=$ none and $4=$ very often" consisting 6 positive items and 4 negative items (number 4,5,7 and 8 ).

Reliability test of Indonesian version of PSS-10 was studied by Pin (2011) with a result of cronbach's alpha score of $0,96 .{ }^{(12)}$ Our study also tested the validity and reliability of Indonesian's version of PSS-10 
which showed all items in this questionnaire is valid and reliable (Cronbach's alpha score $=0,775)$. Total score of $0-13$ demonstrates mild stress; $14-26$ shows moderate stress and $27-40$ shows severe stress.

c. Statistical analysis

Our research used SPSS 22 for all analyses. Univariate analyses are reported as numbers and percentages. Independent variables were analyzed using Chi-square test, Kolmogorov-smirnov test. Statistical significance was set at $p<0.05$. Logistic regression method was used in this study as the multivariate analysis to determine the risk factors of low back pain.

\section{Results}

A total of 3005 middle-aged adults participated in this study, $35.4 \%$ of respondents aged $50-60$ years. $55.9 \%$ of them were male. Respondents with bachelor/master/doctoral degrees were $66.4 \%$. Respondents who were married were $89.7 \%$. Most occupations were private employee $(29.5 \%)$. The majority $(74.7 \%)$ of respondents did not smoke. The $39.7 \%$ respondents rarely did physical exersices, however $47.3 \%$ of respondents had a normal BMI.

Based on calculations using a stress scale, the majority of respondents with a percentage of $57.3 \%$ had moderate stress level with total stress scale value of $14-26$. The $83.3 \%$ of respondents did not have a chronic disease. The majority of respondents had an income of Rp. 5.000.000-Rp. 10.000.000 (27.3\%). The majority of respondents with a percentage of $68.2 \%$ worked for $>10$ years. Of $51.5 \%$ respondents spent working time per day for $>8$ hours with the majority of sitting time $\leq 4$ hours per day $(59.5 \%)$ and tanding $>4$ hours per day while working $(65.9 \%)$ (Table 1$)$. 
Table 1

Demographic characteristics

\begin{tabular}{|llll|}
\hline No & Characteristics & $\mathbf{n}$ & $\%$ \\
\hline 1. & Age & & \\
& 30-39 years old & 942 & 31.3 \\
& $40-49$ years old & 999 & 33.2 \\
& $50-60$ years old & 1064 & 35.4 \\
\hline 2. & Gender & & \\
& Male & 1681 & 55.9 \\
& Female & 1324 & 44.1 \\
\hline 3. & Level of Education & & \\
& No formal education & 23 & 0.8 \\
& Elementary School & 50 & 1.7 \\
& Junior High School & 79 & 2.6 \\
& Senior High School & 857 & 28.5 \\
& Bachelor/Masters/Doctoral & 1996 & 66.4 \\
\hline 4. & Marital Status & & \\
& Married & 2696 & 89.7 \\
& Divorced & 89 & 3 \\
\hline 5. & Occuper Married & 220 & 7.3 \\
\hline & & & \\
\hline
\end{tabular}




\begin{tabular}{|c|c|c|c|}
\hline No & Characteristics & $\mathbf{n}$ & $\%$ \\
\hline & Lecturer & 179 & 6 \\
\hline & Physician & 28 & 0.9 \\
\hline & Military/Police & 373 & 12.4 \\
\hline & Government employees & 346 & 11.5 \\
\hline & State Civil Apparatus & 100 & 3.3 \\
\hline & Lawyer & 10 & 0.3 \\
\hline & Accountant & 6 & 0.2 \\
\hline & Consultant & 7 & 0.2 \\
\hline & Labor & 81 & 2.7 \\
\hline & Entrepreneur & 163 & 5.4 \\
\hline & Housewife & 405 & 13.5 \\
\hline & Private employees & 887 & 29.5 \\
\hline & BUMN employees & 38 & 1.3 \\
\hline & Nurse & 37 & 1.2 \\
\hline & Farmer & 71 & 2.4 \\
\hline & Driver & 19 & 0.6 \\
\hline & Other & 165 & 5.5 \\
\hline & Retired & 61 & 2 \\
\hline & Unemployed & 29 & 1 \\
\hline \multirow[t]{3}{*}{6.} & Smoking Habit & & \\
\hline & Non-consumer & 2244 & 74.7 \\
\hline & Consumer & 761 & 25.3 \\
\hline \multirow[t]{4}{*}{7.} & Physical exercise & & \\
\hline & Grade 1 (Never) & 954 & 31.7 \\
\hline & Grade 2 (Rarely) & 1193 & 39.7 \\
\hline & Grade 3 (Regularly) & 858 & 28.6 \\
\hline 8. & Body Mass Indeks (BMI) & & \\
\hline
\end{tabular}




\begin{tabular}{|c|c|c|c|}
\hline No & Characteristics & $\mathbf{n}$ & $\%$ \\
\hline & Severe thinness & 11 & 0.4 \\
\hline & Mild thinness & 25 & 0.8 \\
\hline & Normal & 1422 & 47.3 \\
\hline & Overweight & 599 & 19.6 \\
\hline & Obesity & 959 & 31.9 \\
\hline \multirow[t]{4}{*}{9.} & Stress Scale & & \\
\hline & Mild (Score 0-13) & 1250 & 41.6 \\
\hline & Moderate (Score 14-26) & 1722 & 57.3 \\
\hline & Severe (Score 27-40) & 33 & 1.1 \\
\hline \multirow[t]{3}{*}{10.} & Chronic disease & & \\
\hline & Yes & 503 & 16.7 \\
\hline & No & 2502 & 83.3 \\
\hline \multirow[t]{6}{*}{11.} & Monthly Income & & \\
\hline & $<$ Rp 1.000.000 & 204 & 6.8 \\
\hline & Rp 1.000.000 - Rp 3.000.000 & 461 & 15.3 \\
\hline & Rp 3.000.000 - Rp 5.000.000 & 770 & 25.6 \\
\hline & Rp 5.000.000 - Rp 10.000.000 & 821 & 27.3 \\
\hline & > Rp 10.000.000 & 749 & 24.9 \\
\hline \multirow[t]{4}{*}{12.} & Working time & & \\
\hline & $<5$ years & 541 & 18 \\
\hline & $5-10$ years & 416 & 13.8 \\
\hline & $>10$ years & 2048 & 68.2 \\
\hline \multirow[t]{3}{*}{13.} & Daily working hours & & \\
\hline & $\leq 8$ hours/day & 1470 & 48.9 \\
\hline & $>8$ hours/day & 1535 & 51.1 \\
\hline \multirow[t]{3}{*}{14.} & Sitting on working hours (daily) & & \\
\hline & $>4$ hours & 1218 & 40.5 \\
\hline & $\leq 4$ hours & 1787 & 59.5 \\
\hline
\end{tabular}




\begin{tabular}{|llll|}
\hline No & Characteristics & $\mathbf{n}$ & $\%$ \\
\hline 15. & Standing on working hours (daily) & & \\
& $>4$ hours & 1979 & 65.9 \\
& $\leq 4$ hours & 1026 & 34.1 \\
\hline
\end{tabular}

Based on univariate analysis, factors such as gender ( $p$-value $=0,001)$, level of education ( $p$ value $=$ $0,012)$, physical exercises ( $p$-value $=0,002), B M I(p$-value $=0,006)$, stress scale $(p$-value $=0,003)$, and working time ( $p$-value $=0,002)$ associated significantly with low back pain (Table 2$)$.

\section{Table 2. LBP Prevalence in the last 12 months}




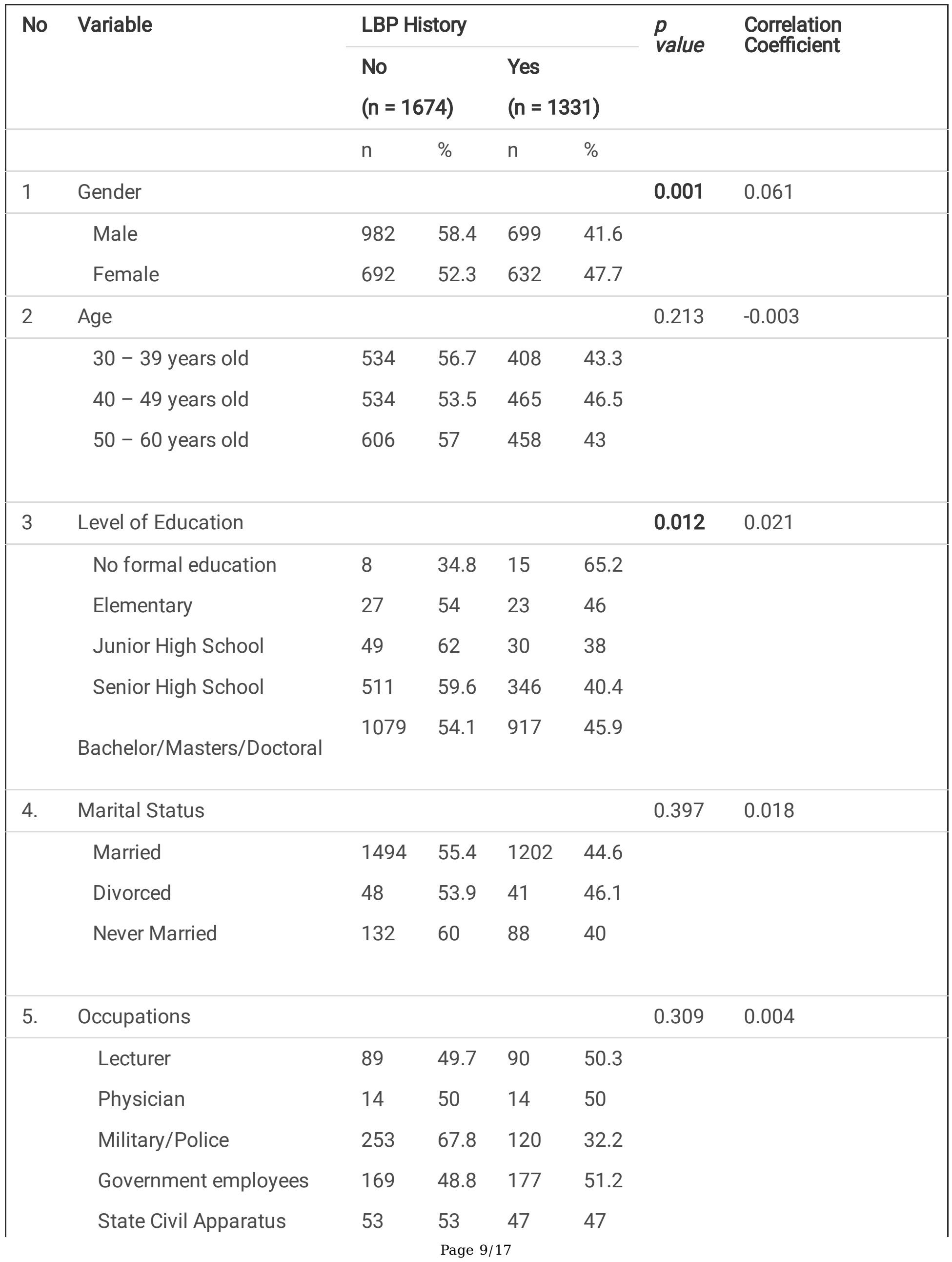




\begin{tabular}{|lllll|} 
Lawyer & 4 & 40 & 6 & 60 \\
Accountant & 4 & 66.7 & 2 & 33.3 \\
Consultant & 4 & 57.1 & 3 & 42.9 \\
Labor & 48 & 59.3 & 33 & 40.7 \\
Entrepreneur & 73 & 44.8 & 90 & 55.2 \\
Housewife & 232 & 57.3 & 173 & 42.7 \\
Private employees & 511 & 57.6 & 376 & 42.4 \\
BUMN employees & 17 & 44.7 & 21 & 55.3 \\
Nurse & 14 & 37.8 & 23 & 62.2 \\
Farmer & 40 & 56.3 & 31 & 43.7 \\
Driver & 10 & 52.6 & 9 & 47.4 \\
Other & 85 & 51.5 & 80 & 48.5 \\
Retired & 37 & 60.7 & 24 & 39.3 \\
Unemployed & 17 & 58.6 & 12 & 41.4 \\
\hline
\end{tabular}


6. Smoking Habit

Non consumer

Consumer $\begin{array}{llll}1234 & 55 & 1010 & 45\end{array}$

$\begin{array}{llll}440 & 57.8 & 321 & 42.2\end{array}$
$0.175 \quad-0.025$

$\mathbf{0 . 0 0 2}-0.062$

7. Physical Exercise

Grade 1 (Never)

$\begin{array}{llll}489 & 51.3 & 465 & 48.7\end{array}$

Grade 2 (Rarely)

$\begin{array}{llll}678 & 56.8 & 515 & 43.2\end{array}$

Grade 3 (Regularly)

$\begin{array}{llll}507 & 59.1 & 351 & 40.9\end{array}$

8. Body Mass Index (BMI)

Severe thinness

Mild thinness

Normal

Overweight

Obesity

9. Stress Scale

Mild (Score 0 - 13)

Moderate (Score 14 - 26)

Severe (Score 27 - 40)

10. Working time

$<5$ years

$5-10$ years

$>10$ years

11. Daily working hours

$\leq 8$ hours/day

$>8$ hours/day

12. Sitting on working hours (daily)

$>4$ hours

$\begin{array}{llll}985 & 55.1 & 802 & 44.9\end{array}$

$\leq 4$ hours

$\begin{array}{llll}689 & 56.6 & 529 & 43.4\end{array}$

$\begin{array}{llll}2 & 18.2 & 1 & 81.8\end{array}$

$\begin{array}{llll}14 & 56 & 11 & 44\end{array}$

$\begin{array}{llll}827 & 58.2 & 595 & 41.8\end{array}$

$\begin{array}{llll}330 & 56.1 & 258 & 43.9\end{array}$

$\begin{array}{llll}501 & 52.2 & 458 & 47.8\end{array}$

$0.006 \quad 0.041$

$\begin{array}{llll}736 & 58.9 & 514 & 41.1\end{array}$

$\begin{array}{llll}925 & 53.7 & 797 & 46.3\end{array}$

$\begin{array}{llll}13 & 39.4 & 20 & 60.6\end{array}$

$0.003 \quad 0.059$

$\begin{array}{llll}327 & 60.4 & 43 & 39.6\end{array}$

$\begin{array}{llll}204 & 49 & 22 & 51\end{array}$

$\begin{array}{llll}1143 & 55.8 & 97 & 44.2\end{array}$

$0.002 \quad 0.02$

$\begin{array}{llll}822 & 55.9 & 648 & 44.1\end{array}$

$\begin{array}{llll}852 & 55.5 & 683 & 44.5\end{array}$

$0.82 \quad 0.004$

13. Standing on working hours (daily)

$>4$ hours

$\begin{array}{llll}574 & 55.9 & 452 & 44.1\end{array}$ 
As for multivariate analysis, factors that significantly associated with low back pain were female gender ( $p$-value $=0,002 ; O R=1,302 ; 95 \% C l=1,098-1,545)$, lack of physical exercises ( $p$-value $=0,005 ; O R=$ $0,872 ; 95 \% \mathrm{Cl}=0,794-0,959)$, higher BMI ( $\mathrm{p}$-value =0,30; OR = 1,094; $95 \% \mathrm{Cl}=1,009-1,187$ ), stress level $(p$-value $=0,002 ; O R=1,259 ; 95 \% \mathrm{Cl}=1,088-1,458)$, and working time $(p$-value $=0,047 ; O R=1,108 ; 95 \% \mathrm{Cl}$ $=1,001-1,225)$ (Table 3).

\section{Table 3. Logistic Regression of Risk Factors Associated with Low Back Pain}

\begin{tabular}{|c|c|c|c|}
\hline Variables & $\begin{array}{l}\text { OR } \\
\text { (Exp B }\end{array}$ & $95 \% \mathrm{Cl}$ & $p$ value \\
\hline \multicolumn{4}{|c|}{ Individual Risk Factors } \\
\hline Gender & 1.3 & $1.098-1.545$ & $0.002^{*}$ \\
\hline Age & 0.98 & $0.891-1.077$ & 0.669 \\
\hline Level of Education & 1.08 & $0.971-1.203$ & 0.155 \\
\hline Body Mass Index & 1.09 & $1.009-1.187$ & $0.002^{\star}$ \\
\hline Smoking Habit & 1.02 & $0.838-1.231$ & 0.872 \\
\hline Physical Exercise & 0.87 & $0.794-0.959$ & $0.005^{\star}$ \\
\hline \multicolumn{4}{|c|}{ Occupational Risk Factors } \\
\hline Working time & 1.1 & $1.001-1.225$ & $0.047^{*}$ \\
\hline \multicolumn{4}{|c|}{ Psychosocial Risk Factors } \\
\hline Stress Level & 1.26 & $1.088-1.458$ & $0.002^{*}$ \\
\hline
\end{tabular}

OR: Odds Ratio; Cl: Confidence Interval; * $\mathrm{p}<0.05$

\section{Discussions}

Low back pain affect productive people and influence an individual's work capacity and overall wellbeing. ${ }^{(13)}$ The prevalence of low back pain is very high and is a major cause of living with disabilities. ${ }^{(14)}$ There are several factors that determine the incidence of LBP such as sociodemographic, ergonomic, and psychosocial factors. ${ }^{(15)}$

\section{LBP prevalence in Indonesian middle age adult}

Our findings showed that the prevalence of LBP in middle-aged adult Indonesian measured at 12 months was $44.29 \%$. This findings were in line with previous systematic study that LBP is occured most in 
persons age $40-80$ years and prevalence $23.2 \pm 2.9 \%$. ${ }^{(1)}$

The prevalence of LBP varies from country to country. ${ }^{(7)}$ Another systematic cohort studies show the prevalence of LBP in the general population is $15-45 \%{ }^{(16)}$ The prevalence of LBP in the general population in Saudi Arabia is $18.8 \% .{ }^{(17)}$ A study about prevalence of LBP in Japan shows a one-month prevalence of $35.7 \%$ and lifetime prevalence of $83.4 \% .^{(18)}$

\section{Risk factors of LBP in middle age adult}

Our study demonstrates gender was associated with LBP. In agreement to other studies, we found that the prevalence of LBP was higher in females than in males. ${ }^{(5,7,19,20)}$ Females tend to have a lower pain threshold than men, therefore they often report the symptoms of LBP than men. ${ }^{21,22)}$ Other studies have reported that that females tend to have a higher risk of LBP because of hormone imbalances. During pregnancy, the hormonal imbalances loose the spinal ligaments that decrease the strength of the lower back muscles and increase the risk of $\operatorname{LBP}(6,23,24)$ Fernandez et al suggested that menopausal osteoporosis caused LBP in women ${ }^{(25)}$ and another study concluded obesity is associated with LBP in women. ${ }^{(26)}$ Another reason of females having more LBP was loads of housework ${ }^{(7)}$, menstruation ${ }^{(27-29)}$.

In agreement with earlier findings, ${ }^{(5,30)}$ our findings suggested that BMI was one of significant risk factors of low back pain. Simsek et al, reported that low back pain was 0.9 times more prevalent in people with higher body mass indeks. ${ }^{(5)}$ A study among healthcare workers also suggested that high BMI was associated with LBP. ${ }^{(31,32)}$ Possible explanations include (1) Increasing mechanical compression in the lumbar spine during movements in obese people possibly enhances mechanical burden (2) The likehood of having of an accident thus possibly increasing the risk of LBP.(3) Adipose tissues produce produces some proinflammatory cytokines (e.g., tumor necrosis factor-a, interleukin-6) that trigger the release of C-reactive protein (CRP), and this statement was supported by the fact that females with normal waist circumference and high CRP have tendency to report LBP than females with low CRP. $(26,32)$

Consistent with other researchs, we observed LPB is more prevalent in people who rarely or never did exercises. $^{(5,6,21,32,33)}$ LBP occurs due to of shortened and weaken back muscles, therefore causes misalignment of the spine. Exercise decreases the event of LBP due to (1) lengthen the back muscles to support and keep the spine in proper alignment. Regular exercise increases blood supply to the spine muscles, joints, and intravertebral discs to minimize injury and increasing repairment. ${ }^{(6,21)}$. (2) Exercise reduces stress and the level of cortisol which increases in stress conditions. ${ }^{(34-36)}$ Other studies have reported that strengthening the spinal muscles by exercises such as stretching or aerobic training decreases LBP by $30 \%$ in terms of intensity of pain and disability. ${ }^{(26)}$

The result of this study suggested that the severity of stress had a significant correlation with low back pain. This study was in line with a study from Korea that confirmed severe stress was correlated with a 2.8-fold increase in risk of chronic low back pain compared to the general population. ${ }^{(37)}$ Stress triggers the secretion of cortisol in the bloodstream. Cortisol is a potent anti-inflammatory hormone, and repeated 
peaked cortisol stimulates cortisol defect. Consequently, this lead to oxidative stress, release free radicals, cellular injury, which lead to chronic pain. ${ }^{(38)}$ Higher cortisol levels are associated with a lower strength of lumbar muscles, resulted in LBP. ${ }^{(6,34)}$

Our study results confirmed that working time was significantly associated with LBP. This fact correlates with a study that focused on nurse, that 5 years of experiences nurses were 3 times more likely to experience LBP. ${ }^{(39-41)}$ The explanation for this fact is, that nurses are more likely to expose to physical and psychological hazards during his/her entire works. ${ }^{(40)}$

The limitation of this study was (1) the sampling method which did not use probability (random) sampling due to the COVID-19 pandemic, so the results might be biased. However, we present a local survei with quite huge number of pupulation. (2) The data of height and body weight might be not original presented because due to pandemic that hinders direct contacts, measurements of height and body weight were not possible.

\section{Conclusions}

Middle-aged adults in Indonesia has a quite high prevalence of LBP. The possible risk factors associated with LBP are female, high body mass index, lack of physical exercise, stress level and working time. Middle-aged adults in Indonesia should be aware of LBP by identifying individual, occupational and psychosocial risk factors that might potentially worsen LBP in the future and to avoid disabilities caused by low back pain.

\section{Abbreviations}

$\mathrm{BMI}$

body mass indeks

LBP

low back pain

\section{Declarations}

\section{Ethics approval and consent to participate}

This study was approved by Clinical Study Ethics Commitee of Pembangunan Nasional Veteran Jakarta University (57/I/2021/KEPK). The respondents had given the approval of consent to participate in this research.

\section{Consent for publication}

Not applicable 
Availability of data and material

The datasets used and/or analysed during the current study available from the corresponding author on reasonable request.

\section{Competing interests}

The authors declare that they have no competing interests

\section{Funding}

We declared no funding related with our study.

\section{Authors' contributions}

TA, NK, worked on collecting data, preparing figures, and manuscript writing. FM reviewed the manuscript. FM is a fully experience neurosurgeon in Jakarta, Indonesia.

\section{Acknowledgements}

Special acknowledgment to the Dean of Faculty of Medicine Universitas Pembangunan Nasional Veteran Jakarta Indonesia.

\section{References}

1. Musculoskeletal Conditions [Internet]. Chinese Herbal Medicine. Stuttgart: Georg Thieme Verlag; 2013. Available from: http://www.thieme-connect.de/products/ebooks/lookinside/10.1055/b-003475016

2. Lezin N, Watkins-Castillo S. The impact of musculoskeletal disorders on Americans-opportunities for action. Burd Musculoskelet Dis United States Prevalence, Soc Econ Cost. 2016;3.

3. Kurniasari A. Krisis Paruh Baya dan Penanganannya. Sosio Inf. 2017;3(2).

4. Lachman ME, Teshale S, Agrigoroaei S. Midlife as a pivotal period in the life course: Balancing growth and decline at the crossroads of youth and old age. Int J Behav Dev. 2015;39(1):20-31.

5. Şimşek Ş, Yağcı N, Şenol H. Prevalence and risk factors of low back pain among health-care workers in Denizli. Agri. 2017;29(2):71-8.

6. Diallo SYK, Mweu MM, Mbuya SO, Mwanthi MA. Prevalence and risk factors for low back pain among university teaching staff in Nairobi, Kenya: a cross-sectional study. F1000Research. 2019;8.

7. Novitasari DD, Sadeli HA, Soenggono A, Sofiatin Y, Sukandar H, Roesli RMA. Prevalence and characteristics of low back pain among productive age population in Jatinangor. Althea Med J. 2016;3(3):469-76.

8. Safarina L, Dewi SN. Pengaruh Senam Yoga Terhadap Skala Nyeri Low Back Pain (LBP) Pada Dewasa Menengah Di Wilayah Kerja Puskesmas Cimahi Tengah. Pros PIN-LITAMAS 1. 
2018;1(1):150-7.

9. Ganesan S, Acharya AS, Chauhan R, Acharya S. Prevalence and risk factors for low back pain in 1,355 young adults: a cross-sectional study. Asian Spine J. 2017;11(4):610.

10. Wicaksono, PD. Validitas dan Reliabilitas Nordic Musculoskeletal Questionnaire ( NMQ ) Pada Kelompok Pekerja Batik Tulis Desa Wisata Giriloyo di Bantul Provinsi Daerah Istimewa Yogyakarta Tahun 2019. Jakarta. Universitas Pembangunan Nasional Veteran Jakarta. 2019

11. Pin, TL. Hubungan antara kebiasaan berolahraga dengan tingkat stres pada mahasiswa FK USU Tahun Masuk 2008. Medan. Fakultas Kedokteran. Universitas Sumatera Utara. 2011

12. Manchikanti L, Singh V, Falco FJE, Benyamin RM, Hirsch JA. Epidemiology of low back pain in adults. Neuromodulation Technol Neural Interface. 2014;17:3-10.

13. Vos T, Barber RM, Bell B, Bertozzi-Villa A, Biryukov S, Bolliger I, et al. Global, regional, and national incidence, prevalence, and years lived with disability for 301 acute and chronic diseases and injuries in 188 countries, 1990-2013: a systematic analysis for the Global Burden of Disease Study 2013. Lancet. 2015;386(9995):743-800.

14. Marras WS, Cutlip RG, Burt SE, Waters TR. National occupational research agenda (NORA) future directions in occupational musculoskeletal disorder health research. Appl Ergon. 2009;40(1):15-22.

15. Hoy D, March L, Brooks P, Blyth F, Woolf A, Bain C, et al. The global burden of low back pain: estimates from the Global Burden of Disease 2010 study. Ann Rheum Dis. 2014;73(6):968-74.

16. Parreira P, Maher CG, Steffens D, Hancock MJ, Ferreira ML. Risk factors for low back pain and sciatica: an umbrella review. Spine J. 2018;18(9):1715-21.

17. Al-Arfaj AS, Al-Saleh SS, Alballa SR, Al-Dalaan AN, Bahabri SA, Al-Sekeit MA, et al. How common is back pain in Al-Qaseem region. Saudi Med J. 2003;24(2):170-3.

18. Fuji T, Matsudaira K. Prevalence of low back pain and factors associated with chronic disabling back pain in Japan. Eur Spine J. 2013;22(2):432-8.

19. 19. Alnaami I, Awadalla NJ, Alkhairy M, Alburidy S, Alqarni A, Algarni A, et al. Prevalence and factors associated with low back pain among health care workers in southwestern Saudi Arabia. BMC Musculoskelet Disord. 2019;20(1):1-7.

20. Bento TPF, dos Santos Genebra CV, Maciel NM, Cornelio GP, Simeão SFAP, de Vitta A. Low back pain and some associated factors: is there any difference between genders? Brazilian J Phys Ther. 2020;24(1):79-87.

21. Kebede A, Abebe SM, Woldie H, Yenit MK. Low Back Pain and Associated Factors among Primary School Teachers in Mekele City, North Ethiopia: A Cross-Sectional Study. Occup Ther Int. 2019;2019.

22. Balakrishnan R, Chellappan ME. Prevalence of low back pain and its risk factors among secondary school teachers at Bentong, Pahang. 2016.

23. Shiri R, Solovieva S, Husgafvel-Pursiainen K, Taimela S, Saarikoski LA, Huupponen R, et al. The association between obesity and the prevalence of low back pain in young adults: the Cardiovascular Risk in Young Finns Study. Am J Epidemiol. 2008;167(9):1110-9. 
24. Heuch I, Hagen K, Heuch I, Nygaard Ø, Zwart J-A. The impact of body mass index on the prevalence of low back pain: the HUNT study. Spine (Phila Pa 1976). 2010;35(7):764-8.

25. 25. Abebe AD, Gebrehiwot EM, Lema S, Abebe TW. Prevalence of low back pain and associated risk factors among Adama Hospital Medical College Staff, Ethiopia. Eur J Prev Med. 2015;3(6):188-92.

26. Karahan A, Kav S, Abbasoglu A, Dogan N. Low back pain: prevalence and associated risk factors among hospital staff. J Adv Nurs. 2009;65(3):516-24.

27. Shiri R, Coggon D, Falah-Hassani K. Exercise for the prevention of low back pain: systematic review and meta-analysis of controlled trials. Am J Epidemiol. 2018;187(5):1093-101.

28. Dos Santos AOB, de Castro JBP, Lima VP, da Silva EB, de Souza Vale RG. Effects of physical exercise on low back pain and cortisol levels: a systematic review with meta-analysis of randomized controlled trials. Pain Manag.

29. Padayachy K, Vawda GHM, Shaik J, McCarthy PW. The immediate effect of low back manipulation on serum cortisol levels in adult males with mechanical low back pain. Clin Chiropr. 2010;13(4):24652.

30. Sugano A, Nomura T. Influence of water exercise and land stretching on salivary cortisol concentrations and anxiety in chronic low back pain patients. J Physiol Anthropol Appl Human Sci. 2000;19(4):175-80.

31. Tsuboi Y, Ueda Y, Naruse F, Ono R. The association between perceived stress and low back pain among eldercare workers in Japan. J Occup Environ Med. 2017;59(8):765-7.

32. Vinstrup J, Jakobsen MD, Andersen LL. Perceived stress and low-Back pain among healthcare workers: a multi-center prospective cohort study. Front Public Heal. 2020;8:297.

33. Mijena GF, Geda B, Dheresa M, Fage SG. Low Back Pain Among Nurses Working at Public Hospitals in Eastern Ethiopia. J Pain Res. 2020;13:1349.

34. ALMaghrabi AO, ALSharif FH, ALMutary HH. Prevalence of Low Back Pain and associated Risk Factors among Nurses-Review.

35. Skela-Savič B, Pesjak K, Hvalič-Touzery S. Low back pain among nurses in Slovenian hospitals: cross-sectional study. Int Nurs Rev. 2017;64(4):544-51.

36. Sribastav S Sen, Long J, He P, He W, Ye F, Li Z, et al. Risk factors associated with pain severity in patients with non-specific low back pain in Southern China. Asian Spine J. 2018;12(3):533.

37. Karunanayake AL, Pathmeswaran A, Kasturiratne A, Wijeyaratne LS. Risk factors for chronic low back pain in a sample of suburban S ri L ankan adult males. Int J Rheum Dis. 2013;16(2):203-10.

38. Nascimento PRC do, Costa LOP. Low back pain prevalence in Brazil: a systematic review. Cad Saude Publica. 2015;31:1141-56. 